In Inheriting Stanley Cavell: Memories, Dreams, Reflections. Edited by David LaRocca. Bloomsbury, 2020, 187-97.

12

\title{
Words Fail Me. (Stanley Cavell's Life Out of Music)
}

\author{
William Day
}

STANLEY CAVELL ISN'T THE FIRST TO ARRIVE AT PHILOSOPHY through a life with music. Nor is he the first whose philosophical practice bears the marks of that life. Jean-Jacques Rousseau "testifies to the harmony between his musical work and his philosophy in his Dialogues." Friedrich Nietzsche saw himself as "the most musical of all philosophers"-presumably more than even his musico-philosophical mentor Arthur Schopenhauer-and asserts in all seriousness that "without music, life would be an error." Ludwig Wittgenstein tells his friend Maurice Drury, "It is impossible for me to say in my book one word about all that music has meant in my life. How then can I hope to be understood? "' (That these are all philosophers Cavell wrote about and cared about shouldn't go unnoticed.) I can't recall when exactly Stanley told me that a highlight of his high school years was playing lead alto sax in an otherwise all-black jazz band; or when I heard the story of his performing at Berkeley in the premiere of an opera by Roger Sessions during which the English horn player had some mishap and Stanley, seated next to him playing clarinet, transposed and played the English horn solo on the spot; or when he confessed to me late in his teaching career, after the first iteration of his opera course, his nearly unbearable, silent anxiety or fear (somehow traceable to his mother's perfect pitch) that in humming or singing an excerpt from an aria in class he might be reproducing the melody in the wrong key. ${ }^{4}$

Much of Cavell's life with music is confirmed for the world in his philosophical autobiography Little Did I Know. The place of that life for Cavell is best captured, to my ear, in the anecdote of what he calls his "impotent 
gallantry." On leaving a New Year's Eve party in Greenwich Village as 1948 became 1949, he offered to escort an African American singer-friend to her apartment up in Harlem. Recalling her unease and eventual admonishment as they walked together north of 125th Street- "Don't you see that you are in far greater danger here than I am? Please go back"-Cavell writes, in partial echo of Wittgenstein's despairing remark to Drury: "It had evidently never occurred to me that a black person would not know by looking at me what my life with music had been and therewith comprehend that that life of mine exempted me from participation in the tragedy of racial injustice." It's possible to read the autobiographer here as admonishing his younger and naive Juilliard-student self. (The autobiographer calls his book, after all, Little Did I Know.) But on what account? Naivete isn't a philosophical error. Self-ignorance, however, is. What strikes the older Stanley in this memory, I think it's clear, is the younger Stanley's youthful failure to recognize that this crucial aspect of his identity doesn't show itself with every step and breath he takes. It is a gentle, convivial admonishment, the kind that a musico-philosophical mentor might give, smilingly, to a student he or she is fond of.

The numerous scattered anecdotes of Cavell's early musical career in Little Did I Know are capped off by an entry, April 10, 2004, describing his eventual realization that he was to leave that career behind-for what exactly, he did not yet know. As his description makes clear, it would take the better part of a lifetime for the leaving to arrive at an end:

Yet this laborious path to nowhere had, I laboriously came to understand, been essential for me. Music had my whole life been so essentially a part of my days, of what in them I knew was valuable to me, was mine to do, that to forgo it proved to be as mysterious a process of disentanglement as it was to have been awarded it and have nurtured it, eliciting a process of undoing I will come to understand in connection with the work of mourning.

Readers of Cavell may well be surprised by the implication that the concept of mourning, a master tone of Cavell's writing from his reading of Thoreau's Walden through his essays on Coleridge and Wordsworth and Emerson's "Experience," should have as one of its originary sites the memory-shock of his leaving his musical life behind. ${ }^{7}$ There is no mention of mourning, notably, in Cavell's description of his family's move, just before he turned seven, from the south side of Atlanta to its north side-an event often highlighted (including by me) in discussions of Little Did I Know. ${ }^{8}$ But mourning will become for Cavell an emblem of the perfectionist work of philosophy itself, which "has to do with the perplexed capacity to mourn the passing of the world." If the emblem of that emblem for Cavell is the abandonment or transformation of his life with music for a life of philosophy, a life dedicated to "the repetitive disinvestment of what has passed," 10 then Cavell's life with music and thoughts about the nature of music ought to be revelatory of Cavell's philosophical life and thoughts.

Is that promising too much? It can seem to overlook the simple, undeniable truth that Cavell's musical performance and improvisational and compositional abilities were after all, pretty completely, when all is said and done, abandoned. It is also true that the singular musical experience Cavell writes about most often-his composing, while at Berkeley, the incidental music for a student production of King Lear-had its greatest impact on him, as he discovered "not without considerable anxiety," 11 for the thoughts it engendered about Shakespeare's play rather than for the music it drew out of him. But then unsurprisingly, as Cavell acknowledges, what leads him into Lear's world is exactly his writing and rehearsing and conducting this music "in response to the play." My concern, in any event, isn't to resuscitate Cavell the musician (though some amateur recordings of him at the piano improvising on popular songs near the end of his life are, I found on the distracted occasions of my hearing them, intriguing). It is to become even more familiar with the philosopher Cavell that our interest in Cavell the musician matters.

The thought I want to follow in these remarks is that Cavell's distinctive orientation in philosophy-call this his lifelong coming to terms with his abandoning a life in music-is guided in part by an interest in those moments in experience where words seem to run out, or veer toward nonsense, leaving in their wake touchstones of ecstasy.

I was introduced to the name "Stanley Cavell" by a musician. John Harbison, the American composer and a long-time friend of Cavell since their meeting in Princeton in 1962, was in the summer of 1981 composer-in-residence at the music festival in Santa Fe, where I was an undergraduate at St. John's College. We met up at one point to talk about music and philosophy (I was making plans, despite or because of St. John's classical curriculum, to write a senior essay on jazz improvisation), and I asked Harbison if he could recommend any contemporary writing on the philosophy of music. That's how I first came to know Cavell's writing voice, a voice I would soon enough learn was indistinguishable from his speaking voice, through the pair of essays Harbison directed me to, "Music Discomposed" and "A Matter of Meaning It."12

Seven-and-a-half years later, on leave from my graduate studies at Columbia to spend a year at Harvard,,$^{13}$ I asked Stanley about musical ineffability. More specifically, I asked whether passages from "Music Discomposed" like the following-passages that picture the scene of exasperation in our trying to explain to someone what we value in some music or other-are depictions of the unsayable:

One is anxious to communicate the experience of such objects. ... I want to tell you something I've seen, or heard, or realized, or come 
to understand, for the reasons for which such things are communicated (because it is news, about a world we share, or could). Only I find that I can't tell you; and that makes it all the more urgent to tell you. I want to tell you because the knowledge, unshared, is a burden-not, perhaps, the way having a secret can be a burden, or being misunderstood; a little more like the way, perhaps, not being believed is a burden, or not being trusted. ... It matters, there is a burden, because unless I can tell what I know, there is a suggestion (and to myself as well) that I do not know. But I do-what I see [or hear] is that (pointing to the object). But for that to communicate, you have to see [or hear] it too. ${ }^{14}$

I remember asking Stanley my question with some urgency, since I had pressed the same question, possibly only days earlier, over lunch with Jim Conant-Jim was about to make his philosophical reputation disabusing readers of the Tractatus who mistakenly find in it a "hidden teaching" that is "inherently inexpressible" 15 - and he had all but persuaded me that the category of the unsayable was a null set.

Stanley was, I'll say, less resolute than Jim in rejecting my suggestion. Still, my reading was off, and in responding to it he offered what I wanted, a rare and detailed gloss on his first essay on music. Stanley's response-I wrote down the gist of it at the time-carried two lines of thought:

1. He said that part of what he was thinking when he wrote that passage was how the imperative "You have to hear it" can discount another's claim to have described what is going on in a piece, even if the other person mouths the same words you would use to say what is going on in it. Cavell's recalling this motive turned my focus to the following two excerpts from the same section of "Music Discomposed":

What I know, when I've seen or heard something is, one may wish to say, not a matter of merely knowing it.... Perhaps "merely knowing" should be compared with "not really knowing": "You don't really know what it's like to be a Negro"; "You don't really know how your remark made her feel"; "You don't really know what I mean when I say that Schnabel's slow movements give the impression not of slowness but of infinite length." You merely say the words.

The paragraph goes on to discuss what place knowing has in these contexts:

The issue in each case is: What would express this knowledge? It is not that my knowledge will be real, or more than mere knowledge, when I acquire a particular feeling, or come to see something. For the issue can also be said to be: What would express the acquisition of that feeling, or show that you have seen the thing? And the answer might be that I now know something I didn't know before. ${ }^{16}$

Knowing in these (moral and aesthetic) contexts doesn't have the shape of a proposition to which is added the appropriate grounding or justifying experience; it has a quite different shape. Knowing here is more like cases of sudden recognition ("I know that face," "I know that move") that can change in a flash every element of one's perception. ${ }^{17}$ To express this knowledge requires that one give expression to those features or that gesture, to that sight or sound. In that light, this section of "Music Discomposed" is not so much about what cannot be said or expressed as about what we mean when we say that we know (or see or hear) a something of this sort. What "Music Discomposed" does say about expressing this knowledge is contained in a single sentence: "Describing one's experience of art is itself a form of art; the burden of describing it is like the burden of producing it." 18

2. Stanley also pointed out, as his teacher J. L. Austin had done, that there is a perfectly trivial sense in which the smell of coffee or the sound of a clarinet, ${ }^{19}$ say, can be put into words. (Just like that. ${ }^{20}$ - But those words, of course, standing by themselves, are hardly an expression of knowledge, at least of the kind of knowledge we are tempted to declare beyond words. Expressing what we know-or showing it, Tractarian-wise-comes easier in some matters than in others.

And yet: Cavell recounts early in Little Did I Know a peculiar gesture of his mother's that seems to serve him as a touchstone for what one might well call music's expressible-but-unsayable aspects-"the great secrets," he writes, "I knew I craved to have" and that his musically gifted mother "seemed to divine." The instance he reports occurred at a recital by the great violinist Fritz Kreisler, for which Stanley (aged ten or eleven) traveled with his mother to San Francisco from their home in Sacramento. At various moments during the recital, particularly at the ends of each of Kreisler's encores, his mother would "suddenly produce (a gesture I knew well and would glory in when directed to something I had done) an all but inaudible high cry and silently snap the fingers of her hand nearer me and thrust it toward her face, which was turned as if to ward off a blow." ${ }^{21}$ (Is there an epistemology that gives us a complete account of this species of knowing, a knowing that is neither propositional nor a mere familiarity nor a knowing how?) If you were to attempt to translate or reduce Stanley's mother's gesture to words- "It is obviously an expression of approval"; "It means, in effect, "exactly right" "-you would thereby invite the response, "But you have to hear it." Part of what that command expresses, we will see, is an awareness that music-making is itself already a kind of saying (for those who have ears to hear). The point is alluded to in Cavell's description of what he took away from Kreisler's playing that day: 
There was a way he stood listening when the piano was playing a solo passage, especially I suppose in a slow movement, his head and body absolutely still, which I retain as an image of total concentration, ending in a single unhurried gesture that brought the violin back beneath the chin and the bow back to the strings at the instant of the violin's next entrance-as if music had been induced to utter itself. ${ }^{22}$

I grant that the "as if" here ("as if music had been induced to utter itself") matters, as the modifier "a kind of" does in my description of music-making as "a kind of saying." But just as the suggestion of a link between music and speech is an ancient and seemingly innocuous one, so is it neither flippant nor mere analogy, not peculiar to Kreisler's somewhat singular and memorable preparation before an entrance. (I clarify or forge the link between music and speech that I associate with Cavell below.)

Words appear to run out at other moments and in other contexts. Twice in Little Did I Know, having said all that seems fitting about a particularly striking experience, Cavell is left sensing that not enough has been said to fully convince his reader, and he concludes by simply affirming his conviction, but without any fear that he has thereby undermined it. I am struck by where these moments occur. Taken in tandem, they appear to link the mysteries of sexual awakening and musical ecstasy. The first-in which, admittedly, the moment of wordless knowing is somewhat whimsicalconcerns the unspoken connection that the not quite seven-year-old Stanley felt between himself and "a girl of crushing beauty" nearly twice his age who, like him, appeared in a children's talent review in Indian dress, but not before appearing before him backstage undressed:

I think that is what I saw, although it took some time for me to understand that she had taken off really all of her clothes, upon which recognition I was propelled from the room by an invisible force of nature, something like a consuming wave of aromatic mist. ... I tried once or twice during the ensuing week of two shows a day to interest this mythical being in the cosmic fact that we were both Indian royalty, by leaving my costume on and stationing myself by the stairs down to the men's dressing room until she walked off the stage and had a chance to remark the closeness of our connection. Evidently I had failed to place myself in clear enough view for that. But I knew what I knew, and it was satisfactory. ${ }^{23}$

The second occasion concerns the particular, polished, professional sound of the all-black (except for a guitarist and himself) rehearsal jazz band in which the fifteen-year-old Cavell played the lead alto saxophone, a band he claims could rival the sound of the best jazz bands of its day:
When he counted off the tempo for a downbeat the ensuing force of sound was so strong that I feared the house could not withstand it, and I was so thrilled by it that I felt I could barely continue playing. ... Everything we played that morning ... was an original composition of Wiley's, not simply an arrangement; and the ideas were more advanced than any I had heard outside of the Ellington band.... I can readily imagine that someone will think my story remembering our sound in Wiley's arrangements for his black band, as it were invoking comparison with the Basie band of that era, belongs on the side of the delusional. I have to say that on somber reflection I do not really or fully believe that. I place it among those experiences of my life about which I am moved to say: I know what I know. ${ }^{24}$

Finding these passages in a philosophical autobiography called Little Did I Know, the reader is all but required to consider how it is that "I know what I know" ("I knew what I knew") says what it does, avoiding triviality.

We can grant that Cavell's story of a secret connection to the Indian princess registers little more than a child's impression, and that the majesty of Wiley's band (absent recorded evidence) is no better than an impression. Given that, the absence of further words, while understandable, can seem protective, even dismissive of doubt, as if the book's title meant, "Little did I know, but I knew this." But these invocations of "I know what I know" should be compared to a remark in Wittgenstein's Investigations to which Cavell often turns. In it, Wittgenstein gives voice to that moment in any explanation of my apparent certainties when my justifications appear exhausted: "Then I-am inclined to say: 'This is simply what I do." "25 Cavell (reading Wittgenstein) interprets the one so inclined not as dismissing the questioner or voicing despair over the possibility of communication, but as holding that inclination in check, perhaps through an awareness of what our understanding each other, after all, rests on. Taking a cue from Cavell's reading, I want to suggest that "I know what I know" in these passages is not intended by Cavell to silence doubters or to mark where words end. Rather, he employs these words to flag a memory, to draw our attention to it, and to acknowledge where a next question must lead-namely, further down the path of such incandescent experiences, with the aim of discovering how these "detours on the human path to death" might help Cavell "achieve my own death." ${ }^{26}$ In the wake of these recaptured memories, in other words, words do not come to an end out of necessity, as if in the presence of something ineffable. They simply stop, awaiting the impulse to more speech (whether from himself or, in reading, from his reader).

But to return to music: What I take to be culminating thoughts on the burden borne by words and their failure appear in Cavell's late essay 
on music, "Impressions of Revolution." ${ }^{27}$ There the sense of our failure to articulate-or more exactly, to conceptualize-what we hear in music draws inspiration from Walter Benjamin's mid-1920s work The Origin of German Tragic Drama (Ursprung des deutschen Trauerspiels). In this study of German baroque tragedy (Trauerspiel literally means "mourningplay") Benjamin declares at one point that "the spoken word [as opposed to music on the one hand, and to written language on the other] is only afflicted by meaning, so to speak, as if by an inescapable disease" so that "meaning is encountered, and will continue to be encountered as the reason for mournfulness," and that "the phonetic tension with speech in the language of the seventeenth century leads directly to music, the opposite of meaning-laden speech." ${ }^{28}$ Cavell ties these remarks to his long-posited idea that what is known as philosophical skepticism is fueled by our alternating fear of and wish for inexpressiveness. He then offers this succinct summary of Benjamin's claim and its resonance with his own: "Music allows the achieving of understanding without meaning, that is to say, without the articulation of individual acts of reference on which intelligibility is classically thought to depend." ${ }^{29} \mathrm{I}$ find in this formulation or epigram a guide for clarifying not only Cavell's thinking about music but the place of musical experience in his thinking about the expressibility of words.

The picture of human understanding ungrounded in individual acts of reference is more than reminiscent of the picture of language that emerges from Wittgenstein's Investigations. In that picture, our ability to speak to one another, and to understand one another, does not rest in some fact of language or some fact about a world that our words attach to, as the philosophical tradition to which Wittgenstein is responding argues. Cavell notes elsewhere that the effort to apply the traditional picture to concepts of experience-Wittgenstein "remembers someone striking himself on the breast in the heat of a philosophical discussion, crying out, "No one else can have THIS pain" "- appears to make sense only if the referring term ("this") remains mysteriously unspecified, "an absolute demonstrative absolutely pointing to an absolute object." 30 Absent such absolute connections, understanding happens, and it happens in a world whose actual mystery we overlook. To give the merest indication of Wittgenstein's picture of that mystery: understanding happens through the human ways or forms of life that we inhabit and find ourselves attuned to, and that we also find ourselves desiring (broadly speaking) - ways or forms of life into which we are inaugurated together with language, and that enable language to work on us and to move us (broadly speaking).

But Cavell's epigram is explicitly characterizing music, not language. And it draws its inspiration from Benjamin, who had implied a contrast between music's happier expressivity and that of (spoken) words, which are "afflicted by meaning," "meaning-laden speech" being "the reason for mournfulness."
Rather than a grief brought on by our words falling short of capturing our experience, Benjamin's concern is with the grief and mourning that follows from speech itself. What we say, we must mean. And yet, what I do with my grief or mourning, my attitude toward words, is not spelled out in this extract from Benjamin's text.

As I read "Impressions of Revolution," we should take "the achieving of understanding without meaning" to be as instructive of the workings of language as it is of music. What happens when we let go of the idea that the primary fact of communication is that words carry meanings (the ones found in a dictionary), or the idea-more to the point-that my understanding you rests on my associating your words with objects in the world, and similar feats of absolute translation? We might, in that case, rethink the following analogy, pitched by someone bearing a life with music: "Understanding a sentence is much more like understanding a theme in music than one might believe" (Wittgenstein's words, quoted by Cavell in the penultimate paragraph of "Impressions of Revolution"). ${ }^{31}$ Wittgenstein continues: "Why is just this the pattern of variation in intensity and tempo [in a musical theme, or in its performance]? One would like to say: 'Because I know what it all means.' But what does it mean? I'd not be able to say." 32 The sense of Wittgenstein's remark, and of Cavell's interest in quoting it (he counts it among the "revolutionary" things Wittgenstein has to say about "the nature of our agreement in speech"), ${ }^{33}$ is not to mark where the ineffable or unfathomable enter into our understanding of a musical theme or a sentence. The point is rather to underscore a fact of unending surprise, that "the impress produced in you by things as they pass and abiding in you when they have passed" 34 -that is, your attending, in just these surroundings, with whatever relation you bear to them, and with what has gone before, to just this tone and mood-is the necessary but sufficient condition that structures our understanding (or our failing to understand) one another. - And so similarly, my capacity to mourn the passing of the world (as of time, or a friend and mentor, or the fact of meaning-laden speech itself) does not depend on something fixed in speech or in the world to which I might still return, but is akin to my ability to follow a musical theme without losing the thread.

\section{Notes}

1 John T. Scott, "The Harmony between Rousseau's Musical Theory and His Philosophy," Journal of the History of Ideas, vol. 59, no. 2, 1998, 287.

2 Georges Liébert, Nietzsche and Music (Chicago: University of Chicago Press, 2004).

3 Maurice O'Connor Drury, "Conversations with Wittgenstein," Recollections of Wittgenstein, ed. Rush Rhees (Oxford: Oxford University Press, 1984), 160. 
4 Cf. Stanley Cavell, Little Did I Know: Excerpts from Memory (Stanford: Stanford University Press, 2010), 73-5, 183; Andrea Olmstead, Conversations with Roger Sessions (Boston: Northeastern University Press, 1987), 107-8.

5 Cavell, Little Did I Know, 172.

6 Ibid., 225; cf. 209.

7 Cavell doesn't make explicit Thoreau's "morning/mourning" pun in his book on Walden-the word "mourning” doesn't appear there-but see Stanley Cavell, The Senses of Walden (New York: Viking Press, 1972), especially chapter 2, "Sentences," where "morning" is paired with "moulting" (and "metamorphosis" and "leaving"); In Quest of the Ordinary: Lines of Skepticism and Romanticism (Chicago: University of Chicago Press, 1988), 44-5, 72-3, 171-2; and This New Yet Unapproachable America: Lectures after Emerson after Wittgenstein (Albuquerque: Living Batch Press, 1989), 83-4; see also David LaRocca, "In the Place of Mourning: Questioning the Privations of the Private," Nineteenth-Century Prose, vol. 40, no. 2, 2013, 227-42.

8 See my "A Soteriology of Reading: Cavell's Excerpts from Memory," Stanley Cavell: Philosophy, Literature and Criticism, ed. James Loxley and Andrew Taylor (Manchester: Manchester University Press, 2011), 76-91; James Conant, "The Triumph of the Gift over the Curse in Stanley Cavell's Little Did I Know," MLN, vol. 126, 2011, 1004-13; Timothy Gould, "Me, Myself and Us: Autobiography and Method in the Writing of Stanley Cavell," Conversations: The Journal of Cavellian Studies, vol. 1, 2013, 4-18; and Chiara Alfano, "A Scarred Tympanum," Conversations, vol. 1, 2013, 19-38.

9 Cavell, This New Yet Unapproachable America, 84.

10 Ibid.

11 Cavell, Little Did I Know, 215.

12 Stanley Cavell, "Music Discomposed" and "A Matter of Meaning It," Must We Mean What We Say? A Book of Essays (New York: Charles Scribner's Sons, 1969; Cambridge: Cambridge University Press, 1976), 180-237.

13 I was by then well on my way to the better part of a lifetime of conversation with Cavell, and also with the remarkable cadre of graduate students studying with him in the mid- to late-1980s at Harvard, a group he would later describe to me, and then in print, as "permanently inspiring" and "providing a continuity of intellectual purpose unmatched in my decades of teaching" (Cavell, Little Did I Know, 476).

14 Cavell, "Music Discomposed," 192-3.

15 James Conant, "Throwing Away the Top of the Ladder," The Yale Review, vol. 79, Spring 1990, 328-64, 329; see also "Must We Show What We Cannot Say?," The Senses of Stanley Cavell, ed. Richard Fleming and Michael Payne (Lewisburg: Bucknell University Press, 1989), 242-83.

16 Cavell, "Music Discomposed," 192.

17 Experiences of sudden (visual or auditory) recognition are the explicit topic of Wittgenstein's late remarks on aspect-seeing, remarks that figure prominently in Part Four of Cavell's The Claim of Reason and that he returned to late in his career. See Stanley Cavell, The Claim of Reason: Wittgenstein, Skepticism, Morality, and Tragedy (Oxford: Oxford University Press, 1979), 354ff.; and his "The Touch of Words," Seeing Wittgenstein Anew, ed. William Day and Victor J. Krebs (Cambridge: Cambridge University Press, 2010), 81-98.

18 Cavell, "Music Discomposed," 193.

19 Cf. Ludwig Wittgenstein, Philosophical Investigations, trans. G. E. M. Anscombe, P. M. S. Hacker, and Joachim Schulte, rev. 4th ed. (Chichester: Wiley-Blackwell, 2009), \$610, \$78.

20 "Nearly everybody can recognize a surly look or the smell of tar, but few can describe them non-committally, i.e. otherwise than as 'surly' or 'of tar." " J. L. Austin, "Other Minds," Philosophical Papers, 3rd ed. (Oxford: Oxford University Press, 1979), 85.

21 Cavell, Little Did I Know, 53.

22 Ibid.

23 Ibid., 21-3. Stanley's contribution to the review was a piano piece entitled "Indian Drums," which our autobiographer says, "I can still play flawlessly on demand," thereby making a rare and explicit gag out of the truth.

24 Ibid., 77

25 Wittgenstein, Philosophical Investigations, $\$ 217$.

26 Cavell, Little Did I Know, 4

27 Stanley Cavell, "Impressions of Revolution," The Musical Quarterly 85, no. 2, 2001, 264-73.

28 Walter Benjamin, The Origin of German Tragic Drama, trans. John Osborne (London: NLB, 1977), 209, 211; quoted both more and less extensively by Cavell in "Impressions of Revolution," 270.

29 Cavell, "Impressions of Revolution," 270.

30 Stanley Cavell, "The Wittgensteinian Event," Reading Cavell, ed. Alice Crary and Sanford Shieh (London: Routledge, 2006), 11.

31 Wittgenstein, Philosophical Investigations, $\$ 527$, as quoted by Cavell, "Impressions of Revolution," 272. (The translation in the revised fourth edition of Investigations reads: "Understanding a sentence in language is much more akin to understanding a theme in music than one may think.")

32 Ibid. For the later Wittgenstein's conception of language as revealed through the lens of his life with music, see my "The Aesthetic Dimension of Wittgenstein's Later Writings," Wittgenstein on Aesthetic Understanding, ed. Garry L. Hagberg (London: Palgrave Macmillan, 2017), 3-29.

33 Cavell, "Impressions of Revolution," 272.

34 Augustine, Confessions, trans. F. J. Sheed, 2nd ed. (Indianapolis: Hackett, 2006), 253 (Conf. XI, xxvii). 